\title{
CHALKEDON ALS ENDE UND ANFANG DIE TRINITARISCHEN UND CHRISTOLOGISCHEN ENTSCHEIDUNGEN DER ALTEN KIRCHE ${ }^{1}$
}

Es ist ein gewagtes Unternehmen, angesichts der komplizierten geschichtlichen Tatbestände eine kurze Übersicht zu den trinitarischen und christologischen Entscheidungen der Alten Kirche zu geben. Dazu soll dieses dogmengeschichtliche Thema noch unter systematischen Aspekten behandelt werden, d.h. es geht nicht nur um die Darstellung dessen, "was und wie es geschehen ist", sondern auch um die Frage nach dem systematischen Ertrag der damaligen dogmatischen Entscheidungen für die heutige Christologie. Es muß deshalb um Verständnis dafür gebeten werden, wenn manches verkürzt dargestellt wird, um die großen Linien herauszuheben, und wenn der Prozeß der Dogmenbildung, der sehr viel verwickelter war, notgedrungen etwas vereinfacht wird. Diese Übersicht geht davon aus, daß die Definition des Konzils von Chalkedon (451) eine Synthese des dogmengeschichtlichen Prozesses in den ersten fünf Jahrhunderten darstellt. Chalkedon ist in dieser Hinsicht ein Ende; aber es hat mit seiner Formel "eine Person in zwei Naturen" das christologische Denken danach weithin bestimmt und normiert. Deshalb ist es auch ein Anfang sowohl für den Rezeptionsprozeß, der nach Chalkedon einsetzte und bis Konstantinopel III (681) dauerte, als auch für das christologische Denken unserer Zeit, jedenfalls im katholischen

1 Gastvorlesung an der Sektion Theologie der Martin-Luther-Universität Halle am 20.10.1981 im Rahmen einer Theologischen Woche zum Gesamtthema .Jesus der Christus. Die Bedeutung Jesu für unseren Glauben an Gott”. und am 28.02. 1984 an der Päpstlichen Teologischen Akademie in Kraków im Rahmen eines Symposiums über „Hauptprobleme der Christologie heute”. Die Vorlesung weiß sich in besonderer Weise den dogmengeschichtlichen Forschungen von Alois Grillmeier verpflichtet. Aus seinen Veröffentlichungen seien genannt: Mit ihm und in ihm. Christologische Forschungen und Perspektiven, Freiburg 1975; Die Einzigartigkeit Jesu Christi und unser Christsein: ThPh 51 (1976). S. 196-243; Jesus der Christus im Glauben der Kirche I. Von der Apostolischen Zeit bis zum Konzil von Chalkedon (451), Freiburg 1979 (im Folgenden zitiert als „A. Grillmeier I"); Gottes Gottheit und Menschheit, in: Neues Glaubensbuch, hrsg. von J. F e i e r und L. V is ch e r, Freiburg-Zürich ${ }^{6} 1973$, S .245-275. Wie sich diese und ähnliche dogmengeschichtliche Untersuchungen für die Systematik auswirken, kann man etwa an der Christologie Walter Kaspers sehen: Jesus der Christus. Grundriß und Aufsätze zur Christologie, Leipzig 1981 (es ist ein um fünf Aufsätze erweiterter Nachdruck der Ausgabe Mainz 1975). Vgl. neuerdings auch W. Kas per, Der Gott Jesu Christi, Mainz 1982, S. 199-245. 
Raum ${ }^{2}$. Chalkedon - Ende o d e r Anfang? So fragte Karl Rahner noch 1954 im dritten Band des monumentalen Werkes „Das Konzil von Chalkedon", das von Alois Grillmeier und Heinrich Bacht herausgegeben wurde ${ }^{3}$. Heute wird man das Fragezeichen sicher streichen können. Chalkedon ist Ende und Anfang zugleich.

Die folgenden Darlegungen gliedern sich in drei Teile. Um an Chalkedon heranzuführen, wird im ersten Teil über die sogenannte „Zwei-Stufen-Christologie" als Grundmodell christologischen Nachdenkens referiert. Damit soll zugleich die biblische Verwurzelung des konziliaren Auslegungsprozesses dargetan werden. Im zweiten Teil wird Chalkedon als Ende, d.h . als Synthese der christologischen Dogmenbildung in der Alten Kirche dargestellt. Im dritten Teil, einem abschließenden kurzen Ausblick, soll Chalkedon als Anfang zur Sprache kommen, als bleibende Vorgabe für eine weitere Interpretation des Glaubens an Jesus Christus.

DER CHRISTUSGLAUBE DES APOSTELS PAULUS ALS GRUNDMODELL FƯR DIE DOGMENGESCHICHTLICHE ENTFALTUNG

Friedrich Loofs, der fast 40 Jahre an der Theologischen Fakultät der Universität Halle gewirkt hat (1887-1926), macht in seinem Leitfaden zum Studium der Dogmengeschichte darauf aufmerksam, daß ,die Beurteilung des geschichtlichen Christus kata sarka und kata pneuma ... das älteste christologische Schema ..., das Grunddatum aller späteren christologischen Entwicklung" ist ${ }^{4}$. Mag auch manche Korrektur an dieser These Loofs angebracht sein ${ }^{5}$, so ist sie in ihrem Grundgedanken doch wohl richtig. Es läßt sich zeigen, daß mit diesem Schema einer „Zwei-Stufen-Christologie” ein so offenes Modell vorliegt, das tatsächlich von der ältesten judenchristlichen Christologie bis hin zu Chalke-

2 Zur Übersicht für die heutige katholische Christologie sei verwiesen auf: W. Kas per, Neuansätze gegenwärtiger Christologie, in: d e r s. Jesus der Christus (Anm 1), S. 348-370, und L. Ull ric h, Jesus Christus - Auslegung Gottes und Modell des Menschseins. Probleme und Thesen der Christologie in der katholischen Dogmatik, in: H. Kirchner (Hrsg.), Die Frage nach Jesus Christus im ökumenischen Kontext. Vier Vorträge zur gegenwärtigen Christologie, Berlin 1980, S. 28-60.

3 A. Grillmeier - H. Ba cht (Hrsg.), Das Konzil von Chalkedon. Geschichte und Gegenwart I-III, Würzburg 1951-54. Der Aufsatz Rahners findet sich III, s. 3-49 und ist abgedruckt unter dem Titel „Probleme der Christologie heute”, in: K. R a h ner, Schriften zur Theologie I, Einsiedeln 1954, S. 169-222, und in: K. R a hn er, Beiträge zur Christologie, Leipzig 1974, S. 17-62. Zu Chalkedon vgl. auch P. Stockmeier, Das Konzil von Chalkedon, in: J. Bl a nk- G. H a s e n$\mathrm{h}$ ü $\mathrm{tl}$ (Hrsg.), Glaube an Jesus Christus, Düsseldorf 1980, S. 102-116.

${ }^{4} \mathrm{~F}$. L o of s, Leitfaden zum Studium der Dogmengeschichte, Fünfte durchgesehene Auflage, hrsg. von K. Al a nd, Zweiter unveränderter Abdruck, 1. Teil, Halle 1951, S. 70. Vgl. W. K a s per, Jesus der Christus (Anm. 1), S. 43.

5 So vor allem an seiner Hypothese einer "Geistchristologie”, vgl. A. G rillme i e r I, S. 200 u.ö. 
don als übergreifende Struktur verstanden werden kann und in dem sich je nach dem benutzten Vokabular das Geheimnis des Gottmenschen Jesus Christus aussagen läßt. Im ersten Teil dieser Darlegungen möchte ich deshalb auf dieses älteste Schema der doppelten Beurteilung Christi eingehen, allerdings eher in einer gerafften und thetischen Weise, also nach Art einer Problemskizze. Für weitere Überlegungen muß auf die einschlägige Literatur verwiesen werden. Übrigens korrespondiert mit diesem dogmengeschichtlichen Ansatz auch weithin der heute systematische Ansatz in der katholischen Christologie. Diese neue systematische Christologie ruht gewissermaßen auf zwei Säulen: auf dem irdischen Jesus von Nazareth und dem Glauben an den auferweckten Christus ${ }^{6}$.

Paulus, Röm 1,3f

Ausgangspunkt der folgenden Überlegungen sei die alte Homologie, die sich bei Paulus Röm 1,3f findet:

„Paulus ... erwählt für das Evangelium Gottes (... V. 2) ... (V. 3) von seinem Sohne

der geworden ist

(V. 4) der eingesetzt ist

aus dem Samen Davids

dem Fleische nach

zum Sohn Gottes in Macht

dem Geist der Heiligkeit nach

seit der Auferstehung von den Toten, von Jesus Christus, unserem Herrn."

Der Glaube des Apostels ist, wie Röm 1,3f ausweist, Christusglaube. Im Bekenntnis zum Herrn Jesus Christus, dem Sohn Gottes, sieht Paulus die Summe des Evangeliums. Daß es um den gekreuzigten und auferstandenen Herrn geht, wird nicht ausdrücklich gesagt, ist für Paulus aber selbstverständlich; denn Gott ist in seinem Herzen aufgeleuchtet und hat ihn erleuchtet zur Erkenntnis des göttlichen Glanzes auf dem Antlitz Christi, wie er 2 Kor 4,6 formuliert. Wie immer man das "liturgische Fragment aus vorpaulinischer Zeit" ", das hinter Röm 1,3f steht, in seinen Vorformen erfaßt, eines ist damit deutlich im paulinischen Kontext gegeben: Paulus verweist mit Emphase auf Jesus Christus als den Sohn Gottes. Für Paulus ist es der Sohn Gottes, den Gott zur Erlösung in die Welt gesandt hat (Röm 8,3; Gal 4,4), den er nicht verschont, sondern für uns alle hingegeben hat (Röm 8,32). Die fides soteriologica, der Erlösungsglaube, der bei Paulus als stellvertretende Sühne, Versöhnung und Rechtfertigung artikuliert wird, ist unlösbar mit der fides christologica, dem Christusglauben verknüpft, so daß Röm 1,3f „das Evangelium vom Sohne Gottes” (vgl. Röm 1,9.15) und

6gl. die in Anm. 2 genannten Übersichten.

7 So E. Kä s e mann, An die Römer. Ein Kommentar, Berlin 1978 (Nachdruck der 2. überarbeiteten Auflage), S. 8. 
Röm 1,16f ,das Evangelium von der Gerechtigkeit Gottes” inhaltlich deckungsgleich sind. Der Sohn Gottes in sich ist der Sohn Gottes für uns - das ist der Glaube des Apostels ${ }^{8}$. Im Rahmen der folgenden Darlegungen interessiert uns naturgemäß die fides christologica, d.h. die Glaubensformel in Röm 1,3f; aber es sollte doch nicht vergessen werden, daß diese christologische Formel bei Paulus im Dienst der fides soteriologica, der Rechtfertigungsbotschaft steht, im Zusammenhang mit Kreuz und Auferstehung. Es geht im Christusglauben des Apostels nie um eine isolierte Christustheorie, sondern immer um das Heil des Menschen, um Erlösung und Rechtfertigung.

Die Glaubensformel hat vermutlich in ihrer ursprünglichen F o r m gelautet:

$$
\text { „Jesus (ist der ) Christus, }
$$

geworden aus dem Samen Davids, eingesetzt zum Sohn Gottes seit der Auferstehung von den Toten" ?.

Das ist ein Bekenntnis zu Jezus als Messias auf Grund seiner Davidssohnschaft und zu Jesus als Messias auf Grund seiner Adoption und Inthronisation zum Sohne Gottes durch die Auferstehung, also im Sinne einer messianischen Königstitulatur ${ }^{10}$. Das könnte ein erster Versuch im judenchristlichen Milieu gewesen sein, um das Geheimnis Jesu im Horizont der damaligen Messiaserwartung zu formulieren. Das Geheimnis seiner Messianität verwirklicht sich danach in ,zwei Stufen”: auf der irdischen Ebene als Nachkomme Davids, auf der himmlischen Ebene als durch die Auferstehung zum Sohn Gottes inthronisierter Messias.

Ein $\mathrm{zw}$ eites $\mathrm{Stadium}$ dieser urtümlichen Homologie hat sich von dem Adoptianismus in bezug auf die Gottessohnschaft Jesu schon weiter entfernt. Betont werden die beiden Stufen der irdischen und himmlischen Ebene auf das Gegensatzpaar kata sarka und kata pneuma gebracht. So lautete die erweiterte Homologie vermutlich:

8 Vgl. etwa G. Bornkamm, Paulus, Berlin 1977 (Nachdruck der zweiten durchgesehenen Auflage), S. 19ff. Wie weit hier ein gegenseitiger Begründungszusammenhang von Christologie und Rechtfertigungsbotschaft vorliegt, bleibe dahingestellt. Beachtesswert ist jedenfalls die Grundthese Käsemanns: „Die Rechtfertigungslehre ist die spezifisch paulinische Deutung der Christologie, wie umgekehrt diese die Grundlage der ersten." (aaO. S 21) Eine umfangreiche Problemskizze zu dem Verhältnis von Christologie und Rechtfertigungslehre aus systematisch-kontroverstheologischer Sicht in ökumenischer Absicht hat unlängst vorgelegt: $\mathrm{O}$. $\mathrm{H}$. Pes ch, „Um Christi willen ...”. Christologie und Rechtfertigungslehre in der katholischen Theologie: Versuch einer Richtigstellung: Cath 35 (1981), S. 15-57.

${ }^{9}$ Zur Rekonstruktion der Glaubensformel vgl. H. Schlier, Die Anfänge des christologischen Credo, in: B. W elte (Hrsg.), Zur Frühgeschichte der Christolagie (OD 51). Freiburg 1970, S. 24f. 40f; ders., Der Römerbrief, Leipzig 1978, S. 22-27.

10 So H. S c hlier, Der Römerbrief, S. 27. 
„Jesus ist der Messias,

geworden aus dem Samen Davids

eingesetzt zum Sohn Gottes de m

dem Fleische $\mathrm{nach}$

Geist der Heiligkeit $\mathrm{nach}$ durch die Auferstehung von den Toten."

Paulinisch ist das Gegensatzpaar kata sarka - kata pneuma nicht, wie Eduard Schweizer, Ernst Käsemann und Heinrich Schlier gezeigt haben ${ }^{11}$. Es wird hier ,,von der Inthronisation Christi als des Gottessohnes gesprochen, und der Geist der Heiligung war die das bewirkende Macht" ${ }^{12}$. Die zwei Stufen wären damit schon zwein Seinsweisen Jesu Christi: die irdische Seinsweise Jesu Christi und die himmlische Seinsweise desselben Jesus. Hagiosýne bezeichnet nach alttestamentlichen und jüdischen Parallelen die Hoheit und Macht Jahwes als Wesenszug seiner doxa. Es ist also der "Geist der Glorie”, in dem Jesus zum Sohn Gottes bestellt wurde ${ }^{13}$. Adolf Schlatter meint zur Stelle: „Wie er durch das Fleisch ein Davidssohn und ein Menschensohn ist, so ist er durch den Geist, der Gott gehört und mit ihm verbunden ist, Gottes Sohn" ${ }^{14}$.

$\mathrm{P}$ a u l u s übernimmt dieses Glaubensbekenntnis, das ,vielleicht in den Bereich eines hellenistischen Judentums in Rom verweist" "15, modifiziert es aber so, daß jedes adoptianistische Mißverständnis der Gottessohnschaft Jesu Christi endgültig ausgeschlossen wird. Er stellt (1.) das „Sohn Gotts” der ganzen Formel voran, ergänzt (2.) die Titulatur ,Jesus der Christus" mit dem Kyrios-Titel und fügt (3.), wie die meisten Exegeten annehmen, dem ,eingesetzt zum Sohn Gottes" das ,in Macht” hinzu. Damit ist sichergestellt, daß Jesus Christus nicht erst durch die Auferstehung Sohn Gottes wird, sondern es auch schon kata sarka, d.h. in seiner irdischen Existenzweise ist. Durch die Auferstehung ist er der "Sohn Gottes in M a h t", d.h. in seiner endgültigen Offenbarkeit. Schlier meint dazu: „Eben di e s e r Sohn Gottes, der er nicht erst wird, sondern immer schon war und jederzeit ist und endlich sich offenbaren wird, ist 'aus der Auferstehung von den Toten' zum 'Sohn Gottes in M a cht' geworden" "18. Durch diese differenzierende Interpretation des Apostels fügt sich die alte Homologie ganz und gar das christologische

11 Ebd. S. 25. A. Grillmeier (I, 84) meint zu diesem Gegensatzpaar kata sarka und kata pneuma in Röm 1,3f, es ,regt eine Wirkungsgeschichte an, deren Eigenart nur im Zusammenhang der nachbiblischen Entwicklung und ihrer Darstellung geklärt werden kann. Sie betrifft nicht nur die beiden Pole (Fleisch-Geist) als solche, sondern auch ihre Verbindung miteinander."

12 E. Kä s e m a n n, aaO. (Anm. 7), S. 9.

${ }_{13}^{13}$ H. S c hlier, Der Römerbrief S. $26 \mathrm{f}$.

14 Zitiert aaO. S. 27, Anm. 37.

15 AoO. S. 27.

16 AaO. S. 25 (Hervorhebung vom Verfasser dieses Aufsatzes). 
Konzept Pauli ein, wie er es auch Phil 2,5-11 beschreibt: Der Sohn, den der Vater gesandt hat, hat sich selbst erhiedrigt und nahm Knechtsgestalt an, entäußerte sich bis zum Tode; er wurde erhöht und ihm der Name des Kyrios gegeben. Die Formel Röm 1,3f beschreibt somit den Weg ein und desselben Gottessohnes, der als Mensch lebte und durch die Auferstehung als Mensch in seiner Gottessohnschaft machtvoll offenbar wurde ${ }^{17}$.

Diese Darlegung der verschiedenen Stadien einer Homologie mit ihrer fortschreitenden Differenzierung und Interpretation gibt uns zugleich ein Modell dafür, was nachneutestamentlich als Dogmengeschichte zu beschreiben ist ${ }^{18}$. Die Interpretation der fides christologica geht weiter; aber mit einem wichtigen Unterschied: Das Zeugnis Pauli ist normgebend, weil es apostolisches Ursprungszeugnis ist. Deshalb ist der Weg zurück zum judenchristlichen Adoptianismus nicht mehr möglich. Auch bei der weitergehenden Interpretation bleibt die Kirche an das apostolische Ursprungszeugnis des Paulus gebunden.

Ignatius von Antiochien, Eph 7,2

Während bei Paulus das Gegensatzpaar kata sarka - kata pneuma noch ,den geschichtlichen Weg des übergeschichtlichen Gottessohnes" (Grillmeier) beschreibt, wird dieses Gegensatzpaar in seiner Wirkungsgeschichte zunehmend zur Umschreibung des Seine Christi selbst verwendet, so daß sarx als Menschheit Christi und pneuma als Gotheit Christi ausgedeutet wird. Diese christologische Pneuma-Sarx-Formel wird zum Vorläufer des Logos-Sarx-Formel und findet sich im Hirten des Hermas, bei Ignatius von Antiochien, Melito von Sardes, ja sogar noch bei Hilarius von Poitiers ${ }^{19}$. Deshalb soll als zweiter Text eine signifikante Stelle aus dem Epheserbrief des Ignatius von Antiochien vorgelegt werden: ${ }^{20}$

17 Vgl. A. Grillmeier I, S. 83; er meint: „Paulus beschreibt hier den geschichtlichen Weg des übergeschichtlichen Gottessohnes wie in Phil 2, 5-11."

${ }_{18} \mathrm{Zu}$ diesem Verständnis von Dogmengeschichte vgl. etwa $\mathrm{K}$. R a h n e r/K. L e hmann, in: MySal I (1965), S. 622-703; 727-782, bes. S. 738ff; J. R a tzinger, Das Problem der Dogmengeschichte in der Sicht der katholischen Theologie, Köln-Opladen 1966 und W. K as per, Tradition als Erkenntnisprinzip. Systematische Uberlegungen zur theologischen Relevanz der Geschichte: ThO 155 (1975), S. 198-215 (Nachdruck in: ThJb, Leipzig 1977/78, S. 101-117).

19 A. Grillmeier I, S. 160, 200, 211, 581. F. Loofs meinte dieses „Beurteilungsschema" (bzw. seine Derivate) auch im 2. Klemenisbrief, bei Irenäus, Tertullian und Novatian zu finden, Leitfaden... (Anm. 4), S. 70ff, 74f, 108f, 115, 124 ,148. Daß die zwei christologischen Formeln Pneuma - Sarx und Logos - Sarx inhaltlich identisch sind, ergibt sich nach Grillmeier (I, S. 200 )besonders aus Justin, Hippolyt und Tertullian.

20 Vgl. zum folgenden A. Grill meier I, S. 198-201. 
a u s Fleisch zugleich geworden

im Fleisch erschienener

im Tod

aus Maria sowohl

zuerst leidensfähig
„Einer ist Arzt

und a us Geist

und ungeworden,

Gott, wahrhaftiges Leben, wie aus Gott, dann leidensunfähig,

Jesus Christus, unser Herr."

Es geht wie in Röm 1,3f um Jesus Christus, unsern Herrn, der nach Ignatius der eine Arzt für das Menschengeschlecht ist. Für Ignatius ist die Lehre von dem einen A r z Christus offensichtlich $\mathrm{H}$ eils le hre. Die Pneuma-Sarx-Formel dient hier eindeutig dazu, um die menschliche Seite und die göttliche Seite dieses einen Arztes, Jesus Christus, zu entfalten. Die antithetische Formel versucht bei aller Unterschiedenheit der göttlichen und menschlichen Wirklichkeit in Christus ebenso deren Einheit hervorzuheben. Eine weitergehende Reflexion findet noch nicht statt. Es hat sich jedoch eindeutig die Blickrichtung gewandelt. Die ignatianische Formel ist offensichtlich schon „statischer" als die von Paulus überlieferte Formel vom ,geschichtlichen Weg des übergeschichtlichen Gottessohnes". Es werden die status, die Zustände des Menschseins und Gottseins des einen Arztes anvisiert. Von der Auferstehung ist keine Rede mehr. Man könnte diese Formel viel eher als „Inkarnationschristologie" deuten, also als "Christologie von oben” oder „Deszendenzchristologie”, zumal Ignatius an anderer Stelle ausdrücklich vom ,fleischtragenden Kyrios" spricht (Smyrna 5,2), also nicht vom "gott-tragenden Menschen”. Allerdings macht Grillmeier auf die „,alles beherrschende heilsökonomische Schau und den soteriologisch anthropologischen Grundton" der ignatianischen Christologie aufmerksam ${ }^{21}$. In diesem Gesamtkontext wahrt auch die Formel von Eph 7,2 ihre Dynamik. Das Interesse an der Lehre von Christus ist bei Ignatius von dessen Heilsbedeutung geleitet, auch der Christusglaube des Ignatius ist Heilsglaube.

\section{Das Glaubensbekenntnis von Chalkedon}

Wir machen einen großen Sprung in der Geschichte von fast $350 \mathrm{Ja}-$ hren und schauen auf die Struktur der Definition von Chalkedon, den dritten Text, der hier vorgelegt werden soll:

„Wir folgen den heiligen Vätern und lehren alle einstimmig, (es ist) zu bekennen: ein und derselbe Sohn, unser Herr Jesus $\mathrm{Chr}$ is tus, 
- vollkommen derselbe in (der) Gottheit und vollkommen derselbe in (der) Menschheit,

- wahrhaft Gott und wahrhaft Mensch derselbe aus Geistseele und Leib,

- wesensgleich dem Vater der Gottheit nach und wesensgleich uns derselbe der Menschheit nach, 'in allem uns gleich, außer der Sünde' (Hebr 4,15),

- vor aller Ewigkeit aus dem Vater geboren der Gottheit nach, in den letzten Tagen aber derselbe unseretwegen und um unseres Heiles willen von Maria, der Jungfrau und Gottesgebärerin, der Menschheit nach; ein und derselbe Christus, Sohn, Herr, Einzigge borener

- in zwei Naturen

unvermischt, unverwandelt, ungetrennt, ungesondert erkennbar, niemals wird der Unterschied der Naturen aufgehoben der Einheit wegen, vielmehr wird gewahrt die Eigenheit jeder der beiden Naturen

- und kommt zusammen zu einer Person und einer Hypostase (Subjekt);

er wird nicht in zwei Personen getrennt oder auseinandergerissen, sondern (ist) ein und derselbe Sohn, Gott, Logos, (der) $\mathrm{Herr}$ Jesus Christus. So haben die Propheten vormals von ihm und Jesus Christus selbst uns gelehrt und so hat es uns das Bekenntnis der Väter überliefert".

Durch die kursiv gedruckten drei Zeilen wird deutlich, daß der Text des Glaubensbekenntnisses aus zwei Teilen besteht. Diese Zeilen betonen die e in e Sohnschaft und den e in en Kyrios. Es geht bei allen Aussagen der Definition um „ein und denselben Sohn unseren Herrn Jesus Christus". Der Sohn Gottes und der Sohn Mariens sind nicht zwei Söhne, sondern ein und derselbe.

Im ersten Teil des Symbolums wird in vier Zeilen - kenntlich gemacht durch die vier Anstriche - antithetisch Gottheit und Menschheit "ein und desiselben Sohnes" beschrieben. Das Symbolum bewegt sich hier von der Struktur her gesehen ganz im Rahmen dessen, was schon Ignatius mit seinen Antithesen oder Paradoxien zum Ausdruck brachte. Es fällt dabei allerdings (1.) auf, wie neben der Herausarbeitung der Antithesen (vollkommen in der Gottheit - vollkommen in der Menschheit, wahrer Gott - wahrer Mensch usw.) immer wieder die Identität, ,desselben" fast penetrant betond wird: ,vollkommen d e r s e l b e der Gottheit und vollkommen derselbe in der Menschheit", ,wahrer Gott und wahrer Mensch derselbe" usw. Außerdem ist (2.) zu beachten, daß diese Antithesen nicht mehr naiv wiederholt werden, son- 
dern daß sich in ihnen der dogmengeschichtliche Prozeß von 150 Jahren spiegelt. Die Antithesen werden mit dem Begriffsinstrumentarium durchsetzt, das auf Grund des Konzils von Nicäa, im Kampf gegen den Apollinarismus und auf dem Konzil von Ephesus ausformuliert wurde. Derselbe ist wahrer Mensch ,,aus Geistseele und Leib", hier wird Apollinaris abgewehrt; der Sohn ist „wesensgleich dem Vater" und ,aus dem Vater geboren" (nicht geworden!), hier wird Arius zurückgewiesen; derselbe ist zu unserem Heil ,,von Maria der Jungfrau, der Gottesgebärerin” geboren worden, hier hört man das Theotokos von Ephesus (431). Man könnte dieses Vorgehen des Konzils fast mit den Zusätzen Pauli in der ihm überlieferten judenchristlichen Formel vergleichen. Tradition kann nicht stereotype Repetition sein, sondern sie muß zur Abwehr von Mißverständnissen präzisieren und damit interpretieren.

Die Eigenleistung des Chalcedonense liegt allerdings im zweiten Abschnitt des Textes. Was im Rahmen der Antithesen auf dem Stand der damaligen Erkenntnis ausgesagt wird, wird nun mit einer philosophischen Begrifflichkeit umschrieben und weitergehend interpretiert. „,Eine Person in zwei Naturen", das ist chalkedonische Kurzformel för die Einheit „desselben Sohnes und Herrn Jesus Christus” und für die Verschiedenheit von Gottheit und Menschheit in demselben Sohn. Die Konzilsväter von Chalkedon betonen ausdrücklich auch in der neuen Interpretation die Kontinuität ihres Glaubensbekenntnisses mit dem Bekenntnis der Väter von Nicäa und der Lehre der Heiligen Schrift des Alten und Neuen Bundes.

Zweifellos ist strukturell gesehen die Kontinuität von der Zwei-Stufen-Christologie, über die Pneuma-Sarx-Formel (von Röm 1,3f und von Ignatius) bis hin zu Chalkedon gegeben. Walter Kasper urteilt: „Das Konzil von Chalkedon verstand seine Zwei-Naturen-Christologie als Interpretation der konkret-geschichtlichen Zwei-Stufen-Christologie" ${ }^{2}$. Allgemeiner formuliert kann eine 1. These den Vergleich der drei vorgelegten Texte zusammenfassen:

„Die (möglicherweise) älteste Christologie des Neuen Testamentes, die sogenannte Zwei--Stufen- Christologie, stellt schon eine so offene Formulierung für das Persongeheimnis Jesu Christi dar, da $B$ in ihrem $R$ ahmen weitere Präzisierungen und ein tieferes Verstehen des apostolischen Christusglaubens bis hin zu Chalkedon möglich wurden." 
CHALKEDON ALS ENDE: DIE SYNTHESE DER CHRISTOLOGISCHEN DOGMENBILDUNG IN DER ALTEN KIRCHE

Das tiefere Verstehen des apostolischen Christusglaubens und seine Interpretation brachte auch eine neue ontologische Begrifflichkeit ins Spiel, um den Erfordernissen der Zeit und der Abwehr von Irrtümern zu dienen. Dem ist jetzt nachzugehen.

Nicäa - „Fundamentalaussage in der kirchlichen Deutung der Inkarnation"

Das entscheidende Konzil der Alten Kirche war zweifellos Nicäa (325). Konstantinopel I (381), Ephesus (431) und Chalkedon (451) wollten eine Interpretation und Präzisierung der fides Nicaena sein. Das eigentliche Symbolum der Väter ist das Glaubensbekenntnis von Nicäa. Treffend meint Alois Grillmeier: „In den christologischen Kontroversen um Ephesus und Chalkedon wuchs dem Nicänum rückschauend der Ruf einer Fundamentalaussage in der kirchlichen Deutung der Inkarnation zu ... Da nämlich das Ereignis der Fleisches-Oikonomia von dem e in en wesensgleichen $\mathrm{S}$ ohn des Vaters ausgesagt wurde, fand man darin die Einheit des Subjekts im Sinne einer 'Christologie von oben' mit ausgesagt" ${ }^{23}$. Nicäa ist die „Fundamentalaussage in der kirchlichen Deutung der Inkarnation." Es formuliert die Intuition der Menschwerdung Gottes und nicht nur seiner Fleischwerdung. Von dem dem Vater wesensgleichen Sohn sagt es, der „stieg für uns Menschen und um unseres Heiles willen herab, wurde Fleisch und Mensch." Dieses "für uns und um unseres Heiles willen", das soteriologische Interesse, ist für Nicäa charakteristisch. Das Heil der Menschen hängt für die Väter von Nicäa ganz und gar an der Menschwerdung Gottes. Nur wenn der Sohn Gottes, der wirklich Gott ist, Mensch wird, kann er Heil schaffen. Dieses soteriologische Interesse zeigt sich auch daran, daß Nicäa kein neues Glaubensbekenntnis formuliert, sondern in eines der palästinensischen Taufsymbola seine Ablehnung des Arius einbaut. Die fides Nicaena ist bewußt „Interpretation des Taufkerygmas” ${ }^{24}$. Das Taufsymbol als Grundlage des Christseins wird so präzisiert und interpretiert, daß damit eine arianische Umdeutung ausgeschlossen wird. Formal gesehen liegt hier wieder ein ähnliches Verfahren vor, wie es bei der Bekenntnisformel Röm 1,3f festgestellt wurde. Dieses soteriologische Interesse muß gebührend beachtet werden. Es geht Nicäa nicht um mü-

23 A. Grillmeier I, S. 413 (Hervorhebung vom Verfasser dieses Aufsatzes).

${ }_{24}$ AoO., S. 386. Vgl. besonders J. N. D. Kel1 y, Altchristliche Glaubensbekenntnisse. Geschichte und Theologie. Berlin 1971 (Nachdruck der Übersetzung der dritten Auflage), S. 226-229. 
Bige Spekulation, sondern um die alles entscheidende Frage, wie uns das Heil von Gott her zukommt. Auch in dieser Hinsicht liegt eine Analogie zu Röm 1,3f und 1,16f vor. Bei Paulus ist die fides christologica (von Röm 1,3f) entscheidend für sein Verständnis des Heils durch die Gerechtigkeit Gottes (Röm 1,16f), wie oben angedeutet wurde.

In der Symbolforschung wird allgemein angenommen, daß die Väter von Nicäa vier Zusätze in das ihnen vorliegende Taufsymbol einfügten ${ }^{25}$. Das Bekenntnis lautet in deutscher Übersetzung (die Zusätze sind kursiv gedruckt): ,Wir glauben an den einen Gott, den allmächtigen Vater, Schöpfer aller sichtbaren und unsichtbaren Dinge, und an den einen Herrn Jesus Christus, den Sohn Gottes, als Einziggeborener gezeugt vom Vater, das heißt a us der Wesenheit des Vaters, Gott von Gott, Licht vom Licht, wahrer Gott vom wahren Gott, gezeugt, nicht geschaffen, wesenseins mit $\mathrm{d}$ e $\mathrm{m} \mathrm{V}$ a te $\mathrm{r}$, durch den alles geworden ist, was im Himmel und was auf Erden ist, der um uns Menschen und um unseres Heiles willen herabgestiegen und Fleisch und Mensch geworden ist, gelitten hat und am dritten Tage auferstanden ist, aufgestiegen $\mathrm{zu}$ den Himmeln und kommen wird, zu richten die Lebenden und Toten. Und an den Heiligen Geist".

(1) Die Geburt aus dem Vater wird präzisiert mit der ersten Zufü-

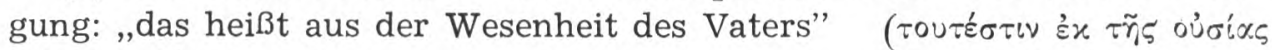

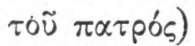

(2) Der Sohn ist nicht nur „Gott von Gott”, das hätten auch die Arianer unterschreiben können, sondern er ist ,wahrer Gott vom wa-

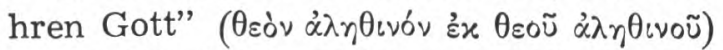

(3) Die dritte Einfügung lautet ,gezeugt nicht geschaffen" ( $\gamma \varepsilon \vee \vee \eta \emptyset \hat{\varepsilon} \vee \tau \alpha$ ou่ $\pi$ oı $\left.\theta_{\varepsilon} \varepsilon_{\tau} \alpha\right)$ Gerade um den Begriff des Zeugens in Abhebung vom

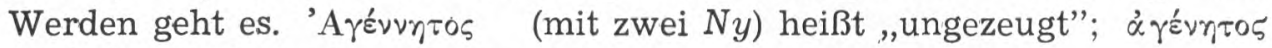
(mit einem $N y$ ) heißt ,ungeworden".

Nicäa (und Athanasius) leitet hier einen Sprachgebrauch ein, der dem Vater das Ungezeugt- und Ungewordensein zuschreibt, während der Sohn zwar gezeugt, aber nicht geschaffen, also auch ungeworden ist. Der Sohn gehört ganz auf die Seite Gottes und nicht auf die der Geschöpfe ${ }^{26}$.

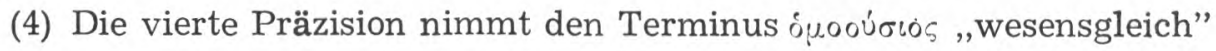

${ }^{25} \mathrm{Vgl}$. etwa Kelly, aaO. S. 233-2316; auch Grill meier I, S. 406ff; zur Interpretation K. Lehmann, Dogmengeschichtliche Hermeneutik am Beispiel der Christologie von Nizäa, in: Jesus - Ort der Erfahrung Gottes, Freiburg 1976, S. 190-209, die Übersetzung des Nicaenums S. 193; vgl. DS 125.

${ }_{26}^{26}$ F. R i cken, Das Homoousios von Nikaia als Krisis des altchristlichen Platonismus, in: B. W elt e (Hrsg.), Zur Frühgeschichte der Christologie (OD 51), Freiburg 1970, S. 84 f. 
auf: „Wesenseins mit dem Vater”. Dieser Ausdruck gehört zu den umstrittenen Begriffen in der Geschichte vor und nach Nicäa. Wir können hier nicht im einzelnen darauf eingehen. Es sei nur darauf verwiesen, daß das Homoousios im Kontext der anderen drei Präzisierungen verstanden werden muß und nicht isoliert $\mathrm{zu}$ sehen ist. Von den anderen Präzisierungen her bestimmt sich seine Aussage, „daß der Sohn wahrer Gott und eigentlicher Sohn ist ... und daß die Geschöpfe mit ihm nichts gemeinsam haben" ${ }^{27}$. Mit anderen Worten, die Einfügung des Homoousios ist auch ein Stück Sprachregelung und „nur vom gezielten, bestimmten Sprachgebrauch der antiarianischen Antwort her zu verstehen" ${ }^{23}$. Weitere Reflexionen sichern dann später nach Nicäa seinen Begriffsinhalt weitgehend ab. Es sei besonders auf Athanasius und die Kappadozier verwiesen ${ }^{29}$.

Dennoch erhebt sich die Frage: Hat Nicäa hier nicht heilsgeschichtliches Denken durch Philosophie, genauerhin Seinsdenken, Ontologie, ersetzt? „Aus dem Wesen des Vaters”, „dem Vater wesensgleich” sind zweifellos Formulierungen hellenistischen Seinsdenkens. Also nochmals: Ist das Kerygma hellenisiert worden? ${ }^{30}$ Hier muß sehr genau aufgemerkt und unterschieden werden zwischen berechtigter und unberechtigter Hellenisierung. Arius (und seine Nachfolger) haben das kosmologisch orientierte System des Mittelplatonismus unvermittelt auf den christlichen Gottesbegriff bezogen und aus dieser unkritischen Parallelisierung von Hen, Nous (und Weltseele) mit Vater, Sohn (und Geist) die Folgerung gezogen: Also kann der Logos (und das Pneuma) nicht Gott im eigentlichen Sinne sein. Diese Lehre leuchtete den Zeitgenossen ein, war es doch die philosophische Weltanschauung der Zeit; aber sie entschärfte das Skandalon der christlichen Botschaft eines menschgewordenen und gekreuzigten Gottessohnes. Nicäa hat mit seinem Festhalten

27 So Ricken, aaO. S. 96. Über die vermutliche Herkunft des Homoousios aus der valentinianischen Gnosis und seine Bedeutung bei der Verurteilung des Paul von Samosata ist hier nicht näher einzugehen, vgl. dazu etwa K elly, aaO. (Anm. 24), S. 240-251.

28 Vgl. K. L e h m a n n, aaO. (Anm. 25), S. 202.

29 Vgl. dazu die einschlägigen Dogmengeschichten, etwa K. A da m, Lehrbuch der Dogmengeschichte I, Berlin 1970 (Nachdruck der 1. durchgesehenem Auflage von 1965), S. 226-240 und K. B els chlag, Grundri der Dogmengeschichte I, Darmstadt 1982, S. 265-270.

30 Die Hellenisierungshypothese ist ein beliebter Topos liberaler Dogmengeschichtsschreibung und wurde bekenntlich von Adolf von $\mathrm{Harnack}$ griffig formuliert, nach ihm ist das Dogma ,ein Werk des griechischen Geistes auf dem Boden des Evangeliums". (Lehrbuch der Dogmengeschichte I, s. 20). Die neuere Forschung hat die Korrekturbediirftigkeit dieser These erwiesen und sie in ihrer Einseitigkeit korrigiert. Hier sei besonders auf zwei Arbeiten von A. Grill meier hingewiesen: Hellenisierung - Judaisierung des Christentums als Deuteprinzipien der Geschichte des kirchlichen Dogmas, in: ders., Mit ihm (Anm. 1), s. 423-488, und Moderne Hermeneutik und altkirchliche Christologie, aaO. s. $489-582$, bes. S. 532-538 zu Nicäa. Vgl. auch die oben zitierten Arbeiten von Ricken (Anm. 26) und Lehmann (Anm. 25), denen wir hier folgen. 
am biblischen Kerygma aus soteriologischem Interesse, die für die zeitgenössische Philosophie schwierigere Lesart gewählt und dieses eingängige Modell verworfen. Nach Nicäa gehört der Sohn auf die Seite des Vaters. Konstantinopel I tut dasselbe mit der Lehre vom Pneuma. So hat Nicäa eigentlich die christliche Botschaft vor dem tödlichen Infekt der arianischen totalen Hellenisierung bewahrt. Und dennoch: Es mußte seine Antwort auf der Höhe der Zeit, d.h. im Rahmen des Seinsdenkens geben, anders wäre seine Botschaft nicht verstanden worden. Dieser notwendige und berechtigte Rückgriff auf griechisches Denken, um die Bibel zu verstehen und zu verteidigen, setzt sich fort bis zu Chalkedon.

In Nicäa beginnt somit, was Grillmeier für Chalkedon feststellt: „,Die Väter von damals haben die Übersetzung der biblischen Sprache in eine ontologische Terminologie gewagt - weil anders für ihre Zeit das biblische Kerygma nicht zu klären und festzuhalten war" ${ }^{31}$. Sachlich stellt die Erklärung des Rates der EKD vom 19.06.1975 anläßlich des Nicäa-Gedenktages dasselbe fest: „,Die Aussagen des Nicänums können nicht als Verfremdung des biblischen Zeugnisses durch den Geist griechischer Philosophie abgewertet werden. Indem das biblische Christuszeugnis mit Hilfe der griechischen Philosophie formuliert wurde, konnte es sachlich unverkürzt festgehalten werden" ${ }^{32}$. Anders ausgedrückt: Die dogmatische Formulierung von Nicäa (wie jede andere) will das Evangelium verstehen helfen. Das Dogma, ,bleibt zurückbezogen auf das Kerygma und sucht es vor voreiligen Übergriffen des menschlichen Denkens zu schützen und $\mathrm{zu}$ retten. Gleichwohl ist es in dieser Funktion unentbehrlich und darum auch in der jeweiligen Grundentscheidung unüberholbar" ${ }^{33}$. Man kann nicht hinter ein einmal aufgebrochenes Problembewußtsein zurückgehen und auch in der Verkündigung des Evangeliums nicht so tun, als sei die Zeit nicht weitergegangen. Die Väter von Nicäa mußten so antworten, wie sie geantwortet haben, das heißt mit Hilfe der zeitgenössischen Philosophie, aber auf dem Boden des Evangeliums.

\section{Chalkedon}

Chalkedon unter doppeltem Blickwinkel: piscatorie - Aristotelice Wenden wir uns nun wieder Chalkedon zu. Seine konziliare Aussage, die Definition, das Symbolum Chalcedonense vom 22.10.451, wird schon von seinen Zeitgenossen in doppelter Weise verstanden. Leitend ist auf

${ }^{31}$ A. Grillmeier, Die Rezeption des Konzils von Chalkedon in der römisch-katholischen Kirche, in: de rs., Mit ihm (Anm. 1), S. 370.

${ }_{32}$ Zitiert nach K. L e h m a n n, aaO. (Anm. 25) S. 203.

$38 \mathrm{AaO}$. S. 204.

25 - Analecta Cracoviensia 
der einen Seite das soteriologisch-kerygmatische Interesse am rechten Christusglauben. Auf der anderen Seite werden anspruchsvollere philosophische Begriffe notwendig, um den Glauben $\mathrm{zu}$ formulieren. Das Glaubensbekenntnis soll die wirkliche Menschwerdung des Gottessohnes unmißverständlich ausdrücken und „die Wirklichkeit der Gottheit und Menschheit in dem einen Christus unmißverständlich aussagen" ${ }^{34}$. Aber diese Aussagen stehen im Dienst des Taufsymbols und des Taufglaubens von Nicäa. Die Formulierung des Glaubensbekenntnisses in anspruchsvolleren philosophischen Begriffen (Person, Natur) wurde notwendig, weil die Auslegung des Taufglaubens von Nicäa im Gegenüber zu offensichtlich falschen Interpretationen in neuer rationaler Reflexion ,,eingeholt" werden mußte. Anders ausgedrückt: Gegen Nestorius und Eutyches mußte Chalkedon auf das inkarnatorische Grundschema von Nicäa, M e n s c hwerdung G ottes, hinweisen. Dieser Hinweis erfolgte jetzt mit philosophischen Begriffen. Grillmeier meint: „Eben dieser 'Intuition' von dem einen Sohn Gottes in wahrer Gottheit und wahrer Menschheit folgt auch das Konzil von Chalkedon ... Wenn dann die mia hypostasis und das hen prosōpon in Jesus Christus ausgesagt wird, dies in zwei Naturen, will das Chalcedonense eben dasselbe in einer begrifflichen Sprache sagen, was vorher als Schema einer absteigenden Christologie im Nicaenum vor Augen gestellt worden war" ${ }^{35}$. Dieses doppelte Anliegen von Chalkedon, das soterologisch-kerygmatischen und das philosophisch-begriffliche, hat ein Zeitgenosse Chalkedons auf die Formel piscatorie - Aristotelice gebracht. Man kann Chalkedon piscatorie, nach Art der Fischer, d.h. vom kerygmatischen Standpunkt aus betrachten. Man kann es aber auch Aristotelice, nach Art des Aristoteles verstehen, d.h. mit philosophischen, reflektierten Begriffen an es herantreten ${ }^{36}$.

${ }^{34}$ A. Grillmeier, „Piscatorie” — „Aristotelice”. Zur Bedeutung der „Formel" in den seit Chalkedon getrennten Kirchen, in: ders., Mit ihm (Anm. 1), S. 291.

${ }^{35} \mathrm{AaO}$., s. 289. In diesem Zusammenhang ist es sehr nützlich, das Vorwort der Definition von Chalkedon zur Kenntnis zu nehmen, das jetzt in Denzinger-Schönmetzer (DS 300) leicht zugänglich ist. Es geht um die „Menschwerdung des Herrn”. Die neuen Häresien stellen die alte Definition von Nicäa in Frage. Chalkedon ist eine notwendig gewordene Interpretation des Glaubens von Nicäa.

${ }^{36}$ Grillmeier macht (in seinem in Anm. 34 zitierten Aufsatz) auf das Zeugnis des sog. Codex Encyclius oder ta Enklykia aufmerksam. Er ist eine Sammlung von Dokumenten zum Konzil von Chalkedon, die aus den Jahren 457/9 stammt und die Kaiser Leo I. im Zusammenhang mit der Usurpation des Patriarchenstuhles von Alexandrien durch Timotheus Alurus anlegen ließ. In diesem Codex sind u.a. 34 Antworten der Bischöfe des Ostens zur Einschätzung des Konzils von Chalkedon enthalten. Ein Bischof hat die genannte Formel von den beiden Weisen, Chalkedon $\mathrm{zu}$ betrachten, ausgesprochen: ,haec ergo breviter piscatorie et non Aristotelice suggessimus." (S. 285 Anm. 7) Das kerygmatisch-soteriologische Interesse ist bei den meisten Antworten leitend: Chalkedon soll den Taufglauben (von Nicäa) wahren. Nach Bischof Basilius von Seleucia geht es um ein rechtes Verstehen des Nicaenum. (S. 286). 
Die gewohnte Terminologie im ersten Teil der Definition - Weithin blieb man nach dem Urteil der Zeitgenossen auf der kerygmatischen Ebene der Beurteilung des Konzils. Das ging so weit, daß man mancherorts „der Formel von Chalkedon die Möglichkeit aberkannte, im Taufunterricht selbst verwendet $\mathrm{zu}$ werden. Nur die Bischöfe sollen sich damit abgeben - und dies vor allem im Krieg mit den Häretikern" ${ }^{87}$. Tatsächlich ist das Symbolum zuerst für die Bischöfe als Maßstab für die rechte Lehre. Darauf weist schon die umständliche Einleitung hin: „Wir lehren, daß zu bekennen ist”, nicht „wir glauben” wie beim Nicaenum. Bei einer solchen Beurteilung lag das Hauptgewicht für die mögliche spätere Rezeption des Symbolums auch auf dem ersten Teil, der das Geheimnis des menschgewordenen Gottessohnes umschreibend aussprach. Besonders die neueren Untersuchungen von André de Halleux haben wohl endgültig den Nachweis erbracht, daß dieser erste Teil des Chalcedonense in Anlehnung an einen Brief Cyrills von Alexandrien formuliert wurde. Es ist der sogenannte Laetentur-Brief, den er an Johannes von Antiochien 433 schreibt und in dem er zu dessen Unionssymbol nach dem Konzil von Ephesus Stellung nimmt ${ }^{38}$. Chalkedon betont mit Cyrill die Identität und Einheit des Subjekts: ,ein und derselbe" und jetzt mit den Worten Cyrills gegen Eutyches die Zweiheit: „,vollkommen in der Gottheit und vollkommen in der Menschheit". Deshalb ist auch im ersten Teil des Chalcedonense die Betonung der doppelten Homoousie oder Konsubstantialität wichtig. Die doppelte Vollkommenheit Jesu Christi ist „Wesensgleichheit mit dem Vater” und „Wesensgleichheit mit uns (Menschen)". Die doppelte Homoousie Christi hatte schon eine lange Geschichte vor Chalkedon. Auch einer der späteren ,monophysistischen" Gegner des Chalcedonense, Timotheus Älurus (der Kater), der 457 heimlich zum Erzbischof in Alexandrien geweiht wurde und 477 verstarb, ,hat im Kampf gegen die radikalen Eutychianer die zweifache Wesensgleichheit Christi als besonderes theologisches

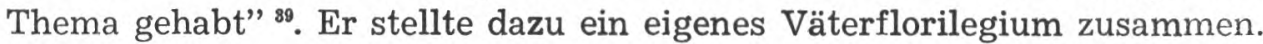

Im Blick auf die nichtchalkedonischen Kirchen meint Grillmeier: „Mit diesem doppelten homoouios Christi ist aber nichts anderes ausgesagt, als was Chalkedon mit den 'zwei Naturen' sagen will. Der Sache nach war man sich eins - nur die Terminologie trat trennend dazwischen" ${ }^{40}$. Gerade der erste Teil des Chalcedonense und sein Verständnis „nach Art der Fischer” zeigt, daß die engere chalkedonische Formel

87 AaO. S. 286.

38 A. de $\mathrm{Halleux,} \mathrm{La} \mathrm{définition} \mathrm{christologique} \mathrm{à} \mathrm{Chalcédoine:} \mathrm{RTL} 7$ (1976), S. 3-32, 155-170; vgl. A. Grillmeier I, S. 755 und ders., Piscatorie (Anm. $34)$, S. $289 f$.

${ }_{39}$ A. Grill me i e r, Piscatorie (Anm. 34), S. 291.

40 Ebd. 
„eine Person in zwei Naturen" nicht die Hauptsache war. Man konnte die Wirklichkeit der Gottheit und der Menschheit in dem e in en Christus auch unmißverständlich anders aussagen. „Wem diese Formel von Chalkedon, Christus eine Hypostase in zwei Naturen, unverständlich war, konnte eine Hilfe finden in den umschreibenden Aussagen, die in der Konzilsdefinition (im ersten Teil) enthalten sind" "

Die ,neue" Terminologie im zweiten Teil der Definition - Wenden wir uns nun der Formel ,eine Person in zwei Naturen” zu. Von vornherein muß gesagt werden, daß die Begriffe Person und Natur zwar ontologische Begriffe sind, daß aber ihre Unterscheidung nicht in der hellenistischen Philosophie vorbereitet war, sondern das Ergebnis christlicher Reflexion ist. Das Konzil gibt mit der Unterscheidung beider Begriffe die Ebenen an, auf der einerseits die Einheit und andererseits die Verschiedenheit in Christus gesehen werden muß. Die Unterschiedenheit betrift die beiden „Vollkommenheiten”: Gottheit und Menschheit Christi. Das nennt das Konzil „Natur”; denn Christus ist „wesensgleich dem Vater" und „wesensgleich uns". Die Einheit betrifft das Subjekt: Jesus Christus ist einer: „ein und derselbe Christus, Sohn”. Das Konzil nennt das Person und gebraucht dafür zwei griechische Worte: prosōpon und hypostasis ${ }^{42}$. Die Einheit liegt also im personalen Bereich und ist keine Einheit „,aus zwei Naturen”, sondern ,i n zwei Naturen”. Dieses ,,in zwei Naturen" und die Einfügung der vier Adverbien „unvermischt, unverwandelt, ungetrennt, ungesondert" ist übrigens die bewußte Eigenschöpfung des Konzils. Es ist eine Verbesserung, die die Revisionskommission entsprechend der Argumentation des Basilius von Seleucia einführte, der vermutlich auch den Grundentwurf für die Definition gemacht hat ${ }^{43}$. Das Konzil hat die beiden Begriffe seiner Formel nicht weiter erklärt oder definiert. Sie müssen also aus der Theologie der damaligen Zeit erklärt werden. Die weitere Klärung war allerdings mit heftigen Auseinandersetzungen verbunden, die eine Trennung in chalkedonische und nichtchalkedonische Kirchen zur Folge hatte. Darauf ist hier nicht weiter einzugehen.

Erwähnt werden soll nur, daß Natur (physis) von Kaiser Markian in

41 AaO. S. 292.

42 A. de $\mathrm{Halleux}$, aaO. (Anm. 38), S. 168, sieht im Prosopon die „manifestation exterieure" und in Hypostasis das "être profond" Jesu Christi. Er schreibt dem Begriff Hypostasis allerdings sekundäre Bedeutung zu (im Gesamt der Gedankenführung der Definitio Chalcedonensis), er sei ein "corollaire de l'affirmation de l'unité fondamentale" (S. 167). Auch Grillmeier, der für den Begriff Hypostasis allerdings an Proclus von Konstantinopel erinnert, meint: ,die Addition von der 'einen Hypostase' nimmt nicht den ersten Platz in der D(efinitio) C(halcedonensis) ein ... Aus dieser Formel wird noch keine 'Christologie' gemacht. Die Auswertung bleibt der Zukunft überlassen." (A. Grill meier I, S. 759; zum folgenden vgl. S. $756 \mathrm{ff})$.

${ }^{43}$ Vgl. A. Grillmeier I, S. 757 f. 
einem Brief unmittelbar nach dem Konzil als „Wirklichkeit, Wahrheit” verstanden wird ${ }^{44}$. Verdeutlichen kann man sich die Unterscheidung von Natur und Person etwa so. Die Frage nach der Natur leutet: „Was”? Es ist die Frage nach der Wesenheit. Die Frage nach der Person lautet: „Wer"? Es ist die Frage nach dem Subjekt oder dem letzten Träger einer Natur. Schon Gregor von Nazianz $(\dagger 390)$ hatte diese Unterscheidung der Sache nach auf die Trinität und Christus angewandt. Er meint

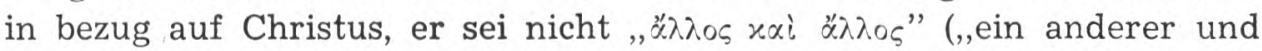

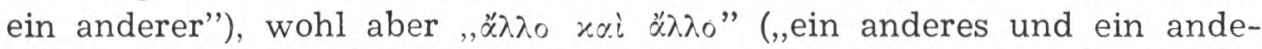
res"). Voraussetzen konnte das Konzil auch das Verständnis des Gregor von Nyssa ( + 394). Er versteht Hypostase als individuelle Existenz. Doch gerade die umschreibenden Bestimmungen in der Definition von Chalkedon und die Wiederholung des "Christus ist ein und derselbe" legt die Bedeutung von Subjekt nahe. Ein Subjekt in göttlicher und menschlicher Existenz. Deshalb ist in der Übersetzung auch Subjekt in Klammern hinter Hypostase gesetzt worden. Die weitere Klärung des Begriffs Person und Hypostase im Gegenüber zu Natur ,ließ lange auf sich warten. Sie gelang nicht auf den ersten Anhieb" 45.

Abschießend können die Ausführungen dieses zweiten Teils in einer 2. These zusammengefaßt werden:

,Das Glaubensbekenntnis von Chalkedon ist das vorläufige Ende des dogmengeschichtlichen Prozesses, der mit Nicäa begann und zur Definition der wahren Gottheit und Menschheit ein und desselben Herrn Jesus Christus, des Sohnes Gottes, führte. Das ist die zeitgemäße Auslegung des apostolischen Ursprungszeugnisses über Jesus Christus, den Sohn Gottes und wahren Menschen, im Rahmen des Problembewußtseins seiner Zeit und mit Hilfe von ontologischen Kategorien".

ABSCHLIEBENDER AUSBLICK: CHALKEDON ALS ANFANG

Im folgenden Ausblick soll kurz auf Chalkedon als bleibenden Anfang hingewiesen werden Chalkedon hat sich mit seiner Definition dagegen gewehrt, die Menschheit Jesu Christi in seiner Gottheit verschwinden zu lassen ,wie ein Tropfen Milch im Meer", um ein dem Eutyches zugeschriebenes Bild zu gebrauchen. Der weitere Denkweg über die Formel von Chalkedon stellt immer mehr die Eigenständigkeit der Men-

44 Vgl. dazu und zum folgenden A. Grillmeier, Piscatorie (Anm. 34), S. $291-298$.

45 AaO. S. 293. 
schheit Jesu heraus, nicht obwohl - sondern w e il es die Menschheit des Gottlogos ist. Hier ist zunächst Le on tius von Jerusalem (Mitte des 6. Jh.) zu nennen. Nach ihm wird die Menschennatur Christi mit ihrer Erschaffung in der Hypostase des Logos subsistent. Gott schafft seinem Sohn in Jesus von Nazareth eine wirkliche menschliche Existenz. „Die Menschennatur Christi hat ihre ganze menschliche Wirklichkeit, ihre Individualität. Aber sie steht nicht in sich selbst als letztes eigenständiges Subjekt, sondern ist die irdisch-begrenzte Existenz des präexistenten Logos" ${ }^{46}$. Besonders ist $\mathrm{M}$ a ximus Confess or ( +662$)$ zu nennen. Er formuliert die Grundeinsicht für ein wirkliches Einswerden des Menschen mit Gott in Christus: „Diese Einheit kann erst dann als vollendet betrachtet werden, wenn die zu einenden Dinge nicht verschwinden, sondern ihre naturhafte Eigenart wahren und doch zu 'einem' zusammengeführt werden" ${ }^{47}$. Maximus formuliert: „Es besteht offensichtlich so weit eine Einung der Dinge, als der physische Unterschied derselben gewahrt wird" ${ }^{48}$. Gottheit und Menschheit werden in Jesus Christus in personaler Einheit verbunden. Eine größere Einheit als diese ist nicht denkbar, weil Gott und Mensch, Schöpfer und Geschöpf unendlich voneinander unterschieden sind und doch in dieser größten Einheit ihre Eigenheit vollendet bewahren. Das Menschsein Jesu „,verschwindet” nicht in der hypostatischen Union. Ganz im Gegenteil: Das Menschsein Jesu Christi ist vollendetes Menschsein, weil es vom Gottlogos getragen wird. Besonders $\mathrm{Karl} R$ ahner hat in seiner Christologie diesen Gedanken weitergeführt. Er versteht „Christologie als die radikalste überbietende Wiederholung der theologischen Anthropologie" ${ }^{49}$. Auch das Vatica n u m II bewegt sich auf dieser Spur, wenn es in der Pastoralkonstitution (GS 41) formuliert: „Wer Christus, dem vollkommenen Menschen folgt, wird auch selbst mehr Mensch." A lois Grillmeier formuliert das so: „In Jesus begegnet uns wirklich der eine und wesensgleiche Sohn Gottes, aber in einer echten menschlichen Existenz, die getragen ist von seiner göttlichen $\mathrm{Hy}$ postase. Die chalkedonische Christologie ermöglicht diese Dialektik: Je mehr ich Christus als Sohn Gottes anerkenne, desto mehr darf ich ihn als den mit uns wesensgleichen Menschen lieben. Je mehr Christus Gott ist, desto mehr ist er auch Mensch" ${ }^{50}$. Schließlich ist noch zu bedenken, daß die Fragen der Ontologie heute als Fragen der Anthropologie verhandelt werden. Dabei spielt das Freiheitsthema zweifellos die

46 AaO. S. 299.

47 AaO. S. 299 f.

1 Opusc. theol. pol. 8; PG 91, S. 97A.

${ }^{49}$ LThK I, S. 626; vgl. K. Rahner, Beiträge zur Christologie, Leipzig 1974.

50 A. Grillmeier, Piscatorie (Anm. 34), S. 300. 
entscheidende Rolle. Gerade das aber war auch das Anliegen der Christologie und Soteriologie des Maximus Confessor. Die in der hypostatischen Einheit begründete Vollendung des Menschseins Jesu Christi ist nach seinem Verständnis auch die Vollendung seiner menschlichen Freiheit. Sehr schön hat das Basil Studer in seiner patrologischen Studie über die Soteriologie des Maximus herausgestellt: „Dieser Mensch (Jesus von Nazareth) konnte nicht menschlicher sein, als er es war, weil der Sohn Gottes selbst in ihm den freien Willen vollbrachte" ${ }^{51}$. Die freie menschliche Entscheidung für Gott ist gerade darin begründet, da $\beta$ sie in der Freiheit Gottes selbst stand. Wer Freiheit sagt, muß auch Geschichte sagen. Echte Geschichte ist kein notwendiger Prozeß, sondern setzt Freiheit voraus. Von daher wird deutlich, daß Chalkedon auch die Grundlage für eine echt menschliche Geschichte des Jesus von Nazareth ist. Erst heute sind wir wohl theologiegeschichtlich gesehen in der Lage, den Begriff einer „Wesensgeschichte” Jesu zu formulieren: Wer Jesus ist, wird in seiner Geschichte deutlich; in seiner Geschichte wird sein Wesen offenbar, ja ereignet sich sein Wesen. Hans Urs von Balthasar hat einmal mit folgenden Worten darauf hingewiesen: „Daß Jesus zu dem wird, was er sowohl vorweltlich wie auch irdisch schon is t, muß in jeder Christologie unbedingt ernst genommen werden" ${ }^{52}$. Damit rückt auch wieder die konstitutive Bedeutung von Kreuz und Auferstehung in der systematischen Christologie in den Vordergrund, und damit wird wieder die Mitte der neutestamentlichen Christologie aufgegriffen.

Dieser stichwortartige Überblick zu Chalkedon als Anfang mag genügen. Er zeigt wenigstens andeutungsweise, in welche Richtung das Ernstnehmen der virklichen Menschheit des Gottlogos führt ${ }^{53}$. Zusammenfassend kann deshalb als 3 . These formuliert werden:

,Um Chalkedon heute zu verstehen, wird man besondersdie Auslegung mit eineranthropologischen Terminologie wagen müssen, die das Freiheitsthema und das geschichtliche Denken gebührendber ücksichtigt. In diesem Sinne ist Chalkedon der bleibende Anfang für eine stets notwendige, vertiefte

51 B. Studer - B. Daley, Soteriologie. In der Schrift und Patristik (HDG III 2a), Freiburg 1978, S. 223 (Hervorhebung vom Verfasser dieses Aufsatzes). Vgl. jetzt auch F. Heinzer, Gottes Sohn als Mensch. Die Struktur des Menschseins Christi bei Maximus Confessor, Freiburg/Schweiz 1980, und F. Heinzer-Chr. $\mathrm{Sch}$ önborn (Hrg.), Maximus Confessor. Actes du Symposium sur Maxime le Confesseur (Par 27), Freiburg/Schweiz 1982.

52 Vgl. H. U. v. Balthas ar, Mysterium Paschale, in: MySal III/2 (1969), S. 273; W. Kas per, Jesus der Christus (Anm. 1), S. 186.

${ }_{53}$ Zur Interpretation des deus vere et homo vere von Chalkedon in der heutigen katholischen Dogmatik darf ich auf meinen Aufsatz (Anm. 2), bes. S. 44-52, verweisen. Diese Vorlesung versteht sich als dogmengeschichtliche Erläuterung dazu. 
Rezeption von Tradition und damit für eine zeitgem $\mathrm{a} ß \mathrm{e}$ In terpretation".

Am Begriff „Menschwerdung Gottes” möge der Unterschied von damals und heute in Sachen Christologie noch einmal markiert werden. Die Alte Kirche legte in Nicäa die Intuition der Menschwerdung Gottes als Glaube der Kirche vor. Bis Chalkedon (und auch in seiner Rezeption danach bis Konstantinopel III) lag der Ton auf „Mensch”: „M e n s c hwerdung Gottes". Heute beginnt man über das Werden nachzudenken. Der Ton liegt auf dem „Werden”: „Menschw e rdung Gottes”. Mit diesen Überlegungen, die Chalkedon weiterführen, wird auch deutlich, daß die Gnade Gottes, die den Menschen vergöttlicht, ihn nicht von sich selbst entfremdet, sondern ihn gerade ins Eigene freisetzt. Je mehr der Mensch mit Gott verbunden und ihm zu eigen wird, um so mehr wird er Mensch, wird sein Menschsein gewahrt und garantiert. Von daher wird endgültig offenbar, wie sehr das christologische Dogma der „Vermenschlichung” des Menschen dient und die Glaubensgrundlage dafür ist. Wenn wir von dieser Sicht her noch einmal auf das soteriologische Interesse des Apostels Paulus, des Ignatius von Antiochien und der Väter von Nicäa und Chalkedon zurückblicken, so kann abschließend als 4 . These formuliert werden:

„Das Heil des Menschen ist für immer mit der Person Jesu Christi verbunden, d.h, der Christusglaube ist vom Erlösungsglauben nicht zu trennen. Das bezeugen alle Stadien der Auslegung des apostolischen Christusglaubens. Im rechten Verständnis der Person Jesu Christi geht es deshalb immer grundlegend um unser eigenes Heil."

CHALCEDON JAKO KONIEC I POCZĄTEK

Trynitarne i chrystologiczne orzeczenia starożytnego Kościoła

Streszcenie

Definicja soboru chalcedońskiego stanowi niewątpliwie pewną syntezę całego procesu, w ramach którego rozwijał się dogmat chrystologiczny na przestrzeni pierwszych pięciu wieków. Pod tym względem Challcedon stanowi koniec: jednalkże przez swoją formułę, ,jedna osoba w dwóch naturach" definiował on późniejiszą myśl chrystologiczną, z naszą dzisiejszą włącznie, i w tym względzie można go widzieć jako początek. K. Rahner przed laty postawił pytanie: Chalcedon - koniec 
czy początek? Dzisiaj można opuścić znak zapytania i twierdzić, że Chal cedon jest końcem i początkiem.

Prezentowane rozważania rozpadają się na trzy części. W pierwszej jest mowa o tzw. „dwustopniowej chrystologii”, dzięki kltórej ujarwni się związek Chalcedonu z Biblią; w drugiej Chalcedon zostaje przedstawiony jako synteza rozwoju dogmatu chrystologicznego (koniec): w trzeciej Chalcedon jest pokazany jako początek dalszych interpretacji wiary w Jezusa Chrystusa.

Chrystologiczna wiara Pawta Apostola zasadniczym modelem rozwoju dogmatu.

Friedrich Loofs zauważył przed laty, że określenie historycznego Chrystusa kata sarka i kata pneuma jest najstarszym chrystologicznym schematem i punktem wyjścia wszystkich późniejszych interpretacji. Z tym schematem koresponduje w pewnym sensie dzisiejsza chrystologia, która usiłuje się wesprzeć na dwóch filarach: na ziemskim Jezusie z Nazaretu i na wierze w zmartwychwstałego Chrystusa.

Punktem wyjścia dla rozważań o „dwustopniowej chrystologii” jest starożytna homologia z Rz 1,3.

„Paweł... oddzielony do (głoszenia) ewangelii Boga (...).. o Jego Synu -

Który co do ciała

pochodził $z$ rodu

Dawida

o Jezusie Chrystusie Panu naszym ${ }^{1}$. zaś według Ducha Swiętości okazał się, dzięki zmartwychwstaniu, Synem Bożym w Mocy

Wiara Apostoła Pawła, jak dowodzi tego $\mathrm{Rz} 1,3 \mathrm{n}$, jest wiarą w Chrystusa. Dla Pawła jest On Synem Bożym, którego Bóg zesłał na świat i za nas wszystkich wydał (Rz 8,32). Wiara w Chrystusa Syna Bożego, w sobie (fides christologica) zespala się u Pawła w jedno z wiarą w zbawienie przez Chrystusa, czyli w Syna Bożego dla nas (fides soteriologica). W dalszych rozważaniach zainteresowanie winno skupiać się na fides christologica, a konkretnie na formule wiary $\mathrm{Rz} 1,3 \mathrm{n}$. Pawłowa formuła wiary brzmiała przypuszczalnie $\mathrm{w}$ pierwotnym przedpawłowym kształcie następująco:

pochodzący z rodu

Dawida

Jezus (jest) Chrystus

okazał się Synem Bożym od zmartwychwstania spośród umarłych.

Zgodnie z tą formułą mesjańska godność Jezusa urzeczywistnia się na „dwóch stopniach": na poziomie ziemskim jest On Mesjaszem jako potomek Dawida, a na poziomie niebieskim jest On przez zmartwychwstanie jako Syn Boży ostatecznie ustanowiony (intronizowany) Mesjaszem. W redakcji Pawła pierwotna formuła została rozszerzona o parę przeciwstawnych pojęć: kata sarka i kata pneuma, którymi zostały uwydatnione obydwa stopnie chrystologicznego ujęcia. W ogóle trzeba powiedzieć, że Pawel, przyjmując to pierwotne wyznanie wiary, zmodyfikował je w taki sposób, żeby wykluczyć z niego wszelkie możliwe nieporozumienia adopcjonistyczne. Szczególnie ważny okazuje się w tym wypadku Pawłowy dodatek okolicznościowy: „w mocy" dołączony do zwrotu „okazał się Synem Bożym”. Jezus Chrystus przez zmartwychwstanie jest „Synem Bożym w mocy”, tzn. w swoim ostatecznym ujawnieniu. Schlier wyjaśnia to zdanie $w$ tym sensie, że ten $\mathrm{Syn}$ Boży, który nie staje się nim dopiero teraz, ale zawsze był i jest nim w każdej chwili, przez zmartwychwstanie stał się „Synem Bożym w mocy”. Dzięki tej uściślającej interpretacji Apostoła starożytna homologia kościelna wtapia się całko-

1 Polski tekst Rz 1, 3n podano w tłumaczeniu: K. Romaniuk, List do Rzymian, Wstęp - Przekład z oryginału - Komentarz, Poznań-Warszawa 1978, s. 76 i 78. 
wicie w chrystologiczną koncepcję Pawła, tak jak ją przedstawia Flp 2, 5-11. To świadectwo Pawła jest miarodajne dla późniejszego rozwoju dogmatu chrystologicznego z tej prostej racji, że posiada autorytet apostolski. Dlatego też stała się raz na zawsze niemożliwa droga wstecz, prowadząca do judeochrześcijańskiego adopcjonizmu.

W okresie poapostolskim para przeciwstawnych pojęc: kata sarka - kata pneuma, która u Pawła opisywała jeszcze „historyczną drogę ponadhistorycznego Syna Bożego", poczyna być stosowana coraz częściej do opisu samego bytu Chrystusa. Przez sarx poczyna się rozumieć człowieczeństwo - a przez pneuma - bóstwo. Ta chrystologiczna formuła pneuma - sarx staje się poprzedniczką formuly Logos - sarx. Występuje ona najwyraźniej w sławnym tekście Ignacego z Antiochii (Ef 7, 2), w którym Jezus Chrystus jest nazwany Jednym Lekarzem, ale zespalającym w sobie ciało (sarx) i ducha (pneuma) i dlatego obdarzonym przymiotami ludzkimi i boskimi. W Ignacjańskim ujęciu można zauważyć poważną zmianę w stosunku do tego, które jest właściwe dla Pawła, w tym mianowicie sensie, że formuła Ignacego jest bardziej statyczna niż formuła Pawła. U Ignacego chodzi o status człowieczeństwa i bóstwa tego „Jednego Lekarza”, bez żadnego odniesienia do historii. Nie ma w niej żadnej wzmianki o zmartwychwstaniu. Formułę tę można interpretować jako wyraz „chrystologii z góry”, lub „chrystologii zstępowania”, tym bardziej, że Ignacy na innym miejscu mówi wprost „o Panu noszącym ciało" (Smyrna 5, 2), a nie o człowieku „noszącym Boga”.

Z kolei wypada zrobić przeskok o 350 lat do przodu i przypatrzyć się strukturze definicji chalcedońskiej: „Idąc za świętymi Ojcami wszyscy jednogłośnie uczymy wyznawać: że jest jeden i ten sam Syn, Pan nasz Jezus Chrystus

- doskonały (ten sam) w bóstwie i doskonały (ten sam) w człowieczeństwie,

- prawdziwy Bóg i prawdziwy człowiek (ten sam) z rozumnej duszy i ciała,

- współistotny Ojcu co do bóstwa i współistotny nam (ten sam) co do człowieczeństwa, ,we wszystkim nam podobny oprócz grzechu” $\mathrm{Hbr} 4,15$,

- przed wiekami z Ojca zrodzony co do bóstwa, a w ostatnich czasach dla nas

i dla naszego zbawienia (ten sam) z Maryi Dziewicy, Bożej Rodzicielki, co do człowieczeństwa: jeden i ten sam Chrystus, Pan, Jednorodzony.

- w dwóch naturach

- bez pomieszania, bez zamiany, bez podziału i bez rozłączenia ma być uznany,

- Nigdy nie została usunięta różnica natur przez ich zjednoczenie,

- lecz raczej zostają zachowane właściwości każdej z dwóch natur,

- i zbiegają się w jednej osobie i jednej hypostazie,

- nie jest On podzielony ani rozerwany na dwie osoby,

- lecz (jest) jeden i ten sam Syn Jednorodzony, Bóg, Logos,

Pan Jezus Chrystus.

- Tak nauczali przedtem o Nim prorocy i sam Jezus Chrystus nas pouczył i tak nam przekazał Symbol Ojców" 2.

Przez podkreślenie trzech wierszy uwidacznia się to, że tekst składa się z dwóch części. Te podkreślone wiersze kładą nacisk na jedno synostwo i jednego Pana. Syn Boży i Syn Maryi nie są dwoma Synami, lecz jednym i tym samym Synem.

W pierwszej części symbolu w czterech wierszach zostało antytetycznie przed-

2 Tłumaczenie polskie wzięte $\mathrm{z}$ BF, VI, 8, poprawione zostało przez autora obecnego streszczenia. Poprawki zostały ujęte w nawiasy okrągłe. 
stawione bóstwo i człowieczeństwo ,jednego i tego samego Syna”. Uderza uporczywe podkreślenie przy każdej antytezie, że chodzi o „Jednego i tego samego". Należy nadito zauważyć, że wypowiedziane antytezy nie ograniczają się do naiwnego powtorzenia tradycyjnych stwierdzeń lecz z rozmysłem włączają w swoją treść osiągnięcia poprzednich Soborów (homousios z Nicei, Theotokos z Efezu).

Ważne dokonanie Chalcedonu wyraża się głównie w części drugiej orzeczenia. Wypowiedziom antytetycznym dodano aparat filozoficzno-pojęciowy. „Jedna osoba w dwóch naturach" jest formułą zastosowaną do wyrażania jedności ,jednego i tego samego Syna" oraz odrębności bóstwa i człowieczeństwa w Nim.

Nie ulega wątpliwości, że istnieje ciągłość między „dwustopniową chrystologią” Pawła, przekazywaną $\mathrm{w}$ schemacie pneuma - sarx przez wieki, a chrystologią orzeczenia chalcedońskiego. Sprawę ciągłości można wypowiedzieć w 1 tezie:

Najstarsza chrystologia NT, tzw. „dwustopniowa chrystologia", prezentuje już na tyle otwarty sposób określenia tajemnicy osoby Jezusa Chrystusa, że w jej ramach stały sie możliwe dalsze uścislenia, głębsze zrozumienie wiary apostolskiej w Chrystusa.

Chalcedon jako koniec: synteza rozwoju dogmatu chrystologicznego $w$ Kościele starożytnym

Najważniejszym soborem starożytnego Kościoła była niewątpliwie Nicea I z 325 roku. Następne sobory chciały być uściśleniem: „tłumaczeniem wiary nicejskiej”. Nicea jest fundamentalną wypowiedzią w kościelnym wyjaśnieniu wcielenia. To ona właśnie uściśliła pojęcie wcielenia pojęciem uczłowieczenia (,i stał się człowiekiem"). Dodatek ten był konieczny z racji soteriologicznych: rozumowano bowiem tak: tylko wtedy gdy Syn Boga, który jest rzeczywiście Bogiem, staje się c złowiekiem, może dokonać naszego zbawienia. W konsekwencji włączono do wyznania wiary przyjętego z lokalnego Kościoła w Palestynie, takie uzupełnienia, które zabezpieczały jednoznacznie bóstwo Zbawiciela. Nicejskiemu wyznaniu wiary czyni się niekiedy zarzut, że poszło w kierunku hellenizacji chrześcijańskiej wiary. Nie da się zaprzeczyć, że pewne pojęcia wprowadzone przez Niceę zostały zaczerpnięte $z$ hellenistycznej filozofii bytu. Jeśli była to hellenizacja to jednak trzeba ją uznać za całkowicie usprawiedliwioną, tzn. taką, która prawdę biblijną wypowiadała w kategoriach zrozumiałych dla ludzi tamtych czasów. Doraźnym jej celem było odrzucenie zupełnie nieusprawiedliwionej hellenizacji, przeprowadzonej przez arianizm. Dogmatyczne określenia soboru nicejskiego miały służyć lepszemu zrozumieniu ewangelii.

Po tych uwagach o Nicei trzeba ponownie powrócić do Chalcedonu. Orzeczenie chalcedońskie było dwojako rozumiane już przez ludzi sobie współczesnych. $\mathrm{Z}$ jednej strony na czoło wysuwał się interes soteriologiczno-kerygmatyczny dotyczący poprawnej wiary w Chrystusa; z drugiej zaś stawały się konieczne bardziej ambitne pojęcia filozoficzne, zdolne dokładnie tę wiarę wypowiedzieć. Ten podwójny zamiar Chalcedonu dobrze wypowiedział jeden ze współczesnych biskupów, mówiąc, że można go rozumieć bądź „piscatorie” bądź „Arystotelice”. W pierwszym wypadku chodziłoby o kerygmatyczny wymiar soboru, a w drugim o filozoficzny sposób wypowiedzenia prawdy wiary (przy pomocy pojęć filozoficznych).

W swym kerygmatycznym charakterze symbol chalcedoński miał służyć przede wszystkim biskupom za kryterium poprawnej nauki. Przy kerygmatycznej ocenie symbolu kładziono głównie nacisk na jego pierwszą część, w której tajemnicę wcielonego Syna Bożego wyrażano w sposób opisowy. Nowe badania historyczne, pro- 
wadzone szczególnie przez A. Halleux wykazały, że ta pierwsza część została ułożona w oparciu o list Cyryla z Aleksandrii, sporządzony z okazji przyjęcia symbolu zgody z 433 roku. W liście tym została mocno podkreślona dwojaka współistotność Chrystusa (względem Ojica i względem nas), którą przyjął i wypunktorwał Chalcedon. Przez podkreślenie dwojakiej współistotności powiedziano to samo, co w następnej części przy pomocy „dwóch natur”. Wszystkim opornym w przyjmowaniu „dwóch natur” należy wskazać drogę przyjęcia tej samej treści przez akceptację dwojakiej współistotności. Warto zauważyć, że monofizyci przyjmują tę formę doktryny o Chrystusie, nie zgadzając się na terminologiczny zwrot "dwie natury".

Wypada jednak zająć się bliżej formułą „jedna osoba w dwóch naturach". Najpierw trzeba stwierdzić, że pojęcia te, jakkolwiek ze swej natury filozoficzne, nie były wcale rozpracowane bliżej w ówczesnej filozofii, lecz wyrastały z refleksji rdzennie chrześcijańskiej, „Osoba” wyrażać ma to samo, co wyrażał w poprzedniej części zwrot ,jeden i ten sam”, czyli jedność podmiotu. Jeden podmiot nie jest $z$ dwóch natur ale $w$ dwóch naturach. Wyrażenie ,w dwóch naturach" i dołączenie czterech przysłówków: „bez zmieszania, bez zamiany, bez podziału i bez rozłączenia", stanowi świadomy, własny wkład soboru w wykład wiary. Sobór nie wyjaśnił bliżej użytych przez siebie zwrotów „osoba” i „natura”. Muszą więc byé wyjaśnione w oparciu o ówczesne rozumienie teologiczne.

Zamykając wywody tej drugiej części można ująć ich wynik w następującej 2. tezie:

Wyznanie wiary z Chalcedonu jest tymczasowym końcem procesu rozwojowego w dziedzinie dogmatu, który (proces) początek swój mial w Nicei i prowadził do zdefiniowania prawdziwego bóstwa i człowieczeństwa jednego i tego samego Pana Jezusa Chrystusa, Syna Bożego. Jest ono odpowiednim do swego czasu odczytaniem apostolskiego przekazu o Jezusie Chrystusie, Synu Bożym i prawdziwym człowieku, w ramach problematyki swojegoczasu i przy pomocy kategorii ontologicznych.

\section{Spojrzenie końcowe: Chalcedon jako poczqtek}

Chalcedon przez swoją definicję obronił człowieczeństwo Chrystusa przed rozpłynięciem się w Jego bóstwie. Późniejsza refleksja nad formułą chalcedońską uwypukla coraz bardziej pełnię człowieczeństwa Jezusa Chrystusa, i to nie wbrew temu - ale właśnie dlatego - że jest to człowieczeństwo Bożego Logosu. Do teologów podkreślających tę ludzką pełnię Chrystusa należą wybitni męžowie tak starożytności, jalk i czasów wispółczesinyıch. Do starożyitności należy Lelontios z Jerozolimy (połowa VI w.) i Maksym Wyznawca, a czasy dzisiejsize reprezentuje K. Rahner.

Leontios uważa, że w Jezusie z Nazaretu Bóg stworzył swojemu Synowi prawdziwie ludzką egzystencję. Maksym Wyznawca uważa, że prawdziwe zjednoczenie dopiero wtedy jest możliwe, kiedy elementy zespalające się nie znikają, lecz zachowując swoje właściwości schodzą się w jedno. W naszych czasach $\mathrm{K}$. Rahner podkreślał, że człowieczeństwo Chrystusa nie ulatnia się w unii hipostatycznej. Nawet sobór Watykański II poszedł po tej drodze twierdząc: „Ktokolwiek idzie za Chrystusem, Człowiekiem doskonałym, sam też pełniej staje się człowiekiem" (KDK 41). W pojęciu pełnego człowieka zawiera się także jego wolność, na którą współcześni są wyjątkowo uwrażliwieni. Z wolnością zaś zespala się pojęcie historii. Historia bowiem nie jest żadnym koniecznym procesem, lecz takim, który zakłada wolność. Chalcedon stanowi słuszną podstawę pod prawdziwie ludzką hi- 
storię Jezusa z Nazaretu. W historii objawia się, a nawet urzeczywistnia się sama istota Jezusa.

Zbierając powyższe rozważania w jedno można sformułować 3. tezę:

Dla zrozumienia Chalcedonu dzisiaj trzeba będzie zaryzykować jego odczytanie w terminologii antropologicznej, która uwzględnia w słusznej mierze zagadnienie wolności i historii. W tym sensie Chalcedon jest trwałym początkiem dla wciąż koniecznej i pogłębionej recepcji tradycji i tym samym dla odpowiedniej do czasu jej interpretacji.

Na koniec należy zauważyć, że w żadnym stadium rozwoju dogmatu wiara w Chrystusa nie była oddzielona od wiary w dokonane przez Niego zbawienie. W poprawnym rozumieniu osoby Jezusa Chrystusa chodzi zawsze ostatecznie o nasze zbawienie. 